\title{
Ice Keel Scour Marks on Mars: Evidence for Floating and Grounding Ice Floes in Kasei Valles
}

\author{
Christopher Woodworth-Lynas and Jacques Yves Guigné \\ Guigné International Ltd. • Paradise, Newfoundland CANADA
}

We present new observations from analyses of Mars Global Surveyor Mars Orbiter Camera images of surficial Martian features interpreted to be the result of interactions between the keels of floating ice masses on submerged sediment. There are two types of features made by grounding ice masses: narrow, intersecting curvilinear trough-like features are ice keel scour marks and are present in large reaches of the Kasei Valles and parts of the Echus Chasma system (Figure 1) and; irregular to sub-circular areas, outlined by small ridges, that represent grounding pits made by large, flat-bottomed ice floes. We base our interpretations on the morphology and local patterns of individual scour marks and ice floe grounding pits. We compare these Mars observations with identical contemporary ice keel grounding structures forming in an analogous environment in the St. Lawrence River on earth.

\section{Background}

If an ocean existed in the north polar basin of Mars, it is reasonable to expect that it may have been seasonally partly or fully covered by floating sea ice (e.g. Luchitta et al., 1986) as is the case for the Arctic and Southern Oceans on Earth. Similarly, it is reasonable to expect that at temperate latitudes large rivers emptying into a cold ocean could carry significant volumes of river ice out into the ocean as, for example, the St. Lawrence River does each spring. Floating ice (river ice, lake ice, sea ice or icebergs) commonly leaves geological traces of its former presence through the creation of ice keel scour marks on the seafloor (Figure 2). One way to test the hypothesis of ice-covered rivers and of an ice-covered ocean on Mars is to search for ice keel scour marks that may be preserved on ancient sedimentary flood surfaces.

Scour marks are the tracks made by floating ice masses as their keels mechanically plough into soft sediments of lake, river or ocean floors. On Earth scour marks are ubiquitous features on the seafloors of the modern Canadian Arctic and sub-arctic regions from Baffin Bay to the Grand Banks and on the Beaufort Sea and Russian polar continental shelves, as well as on the circumpolar seafloor on the continental margin of Antarctica. Scour marks on the modern seafloor may range from present day to 10 or 20 thousand years in age.
Scour marks commonly survive the transition from submergence to exposure above water level and ancient features are commonly seen, for example, over large areas of southern Manitoba and parts of southern Ontario formerly occupied by glacial Lake Agassiz (Figure 3) and glacial Lake Iroquois (Gilbert et al., 1992). They are also found on several large islands of the Arctic Archipelago (e.g. King William Island, Victoria island) and are readily identified from aerial photographs. These relic features were formed in large pro-glacial lakes and (in the Arctic) areas formerly submerged below sea level some 10,000 years ago (Woodworth-Lynas and Guigné, 1990). Scour marks preserved in Pre-Cambrian, Ordovician and Carboniferous/Permian age glacimarine sediments have also been identified on exposed bedding plane surfaces in several localities worldwide (WoodworthLynas, 1992).

On Earth, scour marks form today in water depths from $<5-500 \mathrm{~m}$, and fall in the range $<100 \mathrm{~m}$ to several kilometers long, 5-100 m wide and $<1-5$ m deep (exceptionally $25 \mathrm{~m}$ ). The surface morphology of scour marks typically comprises a curvilinear trough from which seabed material has been excavated and ploughed up and to the sides by the entrenched, moving ice keel, to form two co-linear berms of excavated material. Scour marks commonly occur in extensive and numerous criss-crossing populations. The orientations and distributions of scour marks can be linked to wind and current directions and to long-term changes in sea levels and ice regimes.

\section{Rationale}

In the analysis we examined several hundred high resolution narrow angle images acquired by the Mars Orbiter Camera (MOC). We restricted our initial search for ice keel scour marks to the margins of Chryse Planitia in the vicinity of an ancient shoreline, Contact 2 (proposed by Parker et al., 1993 and largely substantiated by Ivanov and Head, 2001), and to the valley floor regions of the six great valley systems that empty into Chryse: the Mawrth, Ares, Tiu, Simud, Maja and Kasei Valles systems. We searched these regions because it was felt that floating ice masses, either river ice carried out into an ocean from the valleys, or sea ice, 
Figure 1. Relief map of Kasei Valles with location of Mars Orbiter Camera (MOC) images shown in this article. Context relief image from the Mars 2001 Odyssey THEMIS website (http://themis-data. asu.edu/).
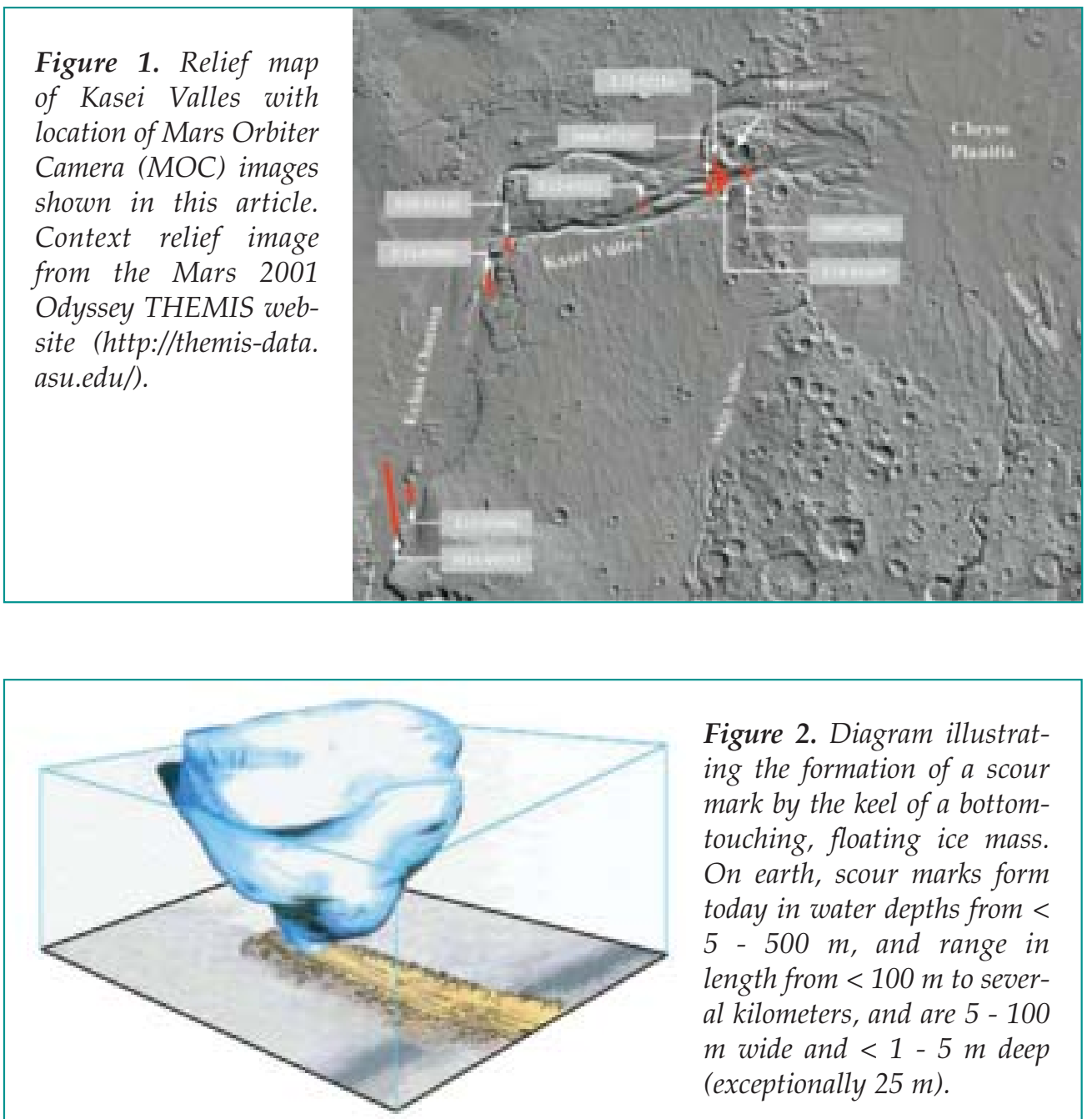

Figure 2. Diagram illustrating the formation of a scour mark by the keel of a bottomtouching, floating ice mass. On earth, scour marks form today in water depths from < 5 - $500 \mathrm{~m}$, and range in length from $<100 m$ to several kilometers, and are $5-100$ $m$ wide and $<1-5 m$ deep (exceptionally $25 \mathrm{~m}$ ). would likely ground and scour in the littoral waters of a river mouth and nearshore region, and that traces of this activity may well be preserved on exposed surfaces of the most recent deposits.

\section{Description of}

\section{Martian Features}

Networks of Parallel Sided Troughs with Berms

On the flat valley floor of Kasei Valles, and in places in Echus Chasma, we have found networks of curvilinear, parallel-sided troughs that meander and intersect with no consistent orientation (Figures 4, 5 and 6). In most areas the troughs are cut into a typically roughtextured surface that characterizes the flat valley floor, and the troughs are always of darker albedo than the rough-textured valley floor.

Wherever they are seen the troughs typically are at least $1 \mathrm{~km}$ long and some exceed 3 and $4 \mathrm{~km}$, and range in width from $10-50$ m. By observing sun shadows it is possible to distinguish narrow ridges, or berms, on one or both sides of most troughs. Where berms are not observed, and where the sun angle is more or less orthogonal to the troughs, shadows are cast on the side nearest the sun, and bright, illuminated margins form the other side. In Kasei Valles some troughs close to the valley margins are buried beneath talus slopes (Figure 6). In addition, in places multiple, overlapping sub-parallel troughs coalesce into wide $(100-300 \mathrm{~m})$, irregular-sided grooved and ridged surfaces (Figure 6).

In Echus Chasma we discovered a group of multiple troughs in a zone about $1.5 \mathrm{~km}$ wide that all curve in the same direction and that terminate in a zone of poorly-defined low ridges oriented roughly orthogonal to the troughs (Figure 7). In addition, we found multiple curvilinear features, defined by three or more closely-spaced parallel troughs (Figure 8).

\section{Ridge-bounded Regions}

Associated with the troughs are poorly- to moderately well-defined irregular to rounded, smooth, low albedo regions, the margins of which are defined by low continuous ridges (e.g. Figures 4, 7 and 8). These 

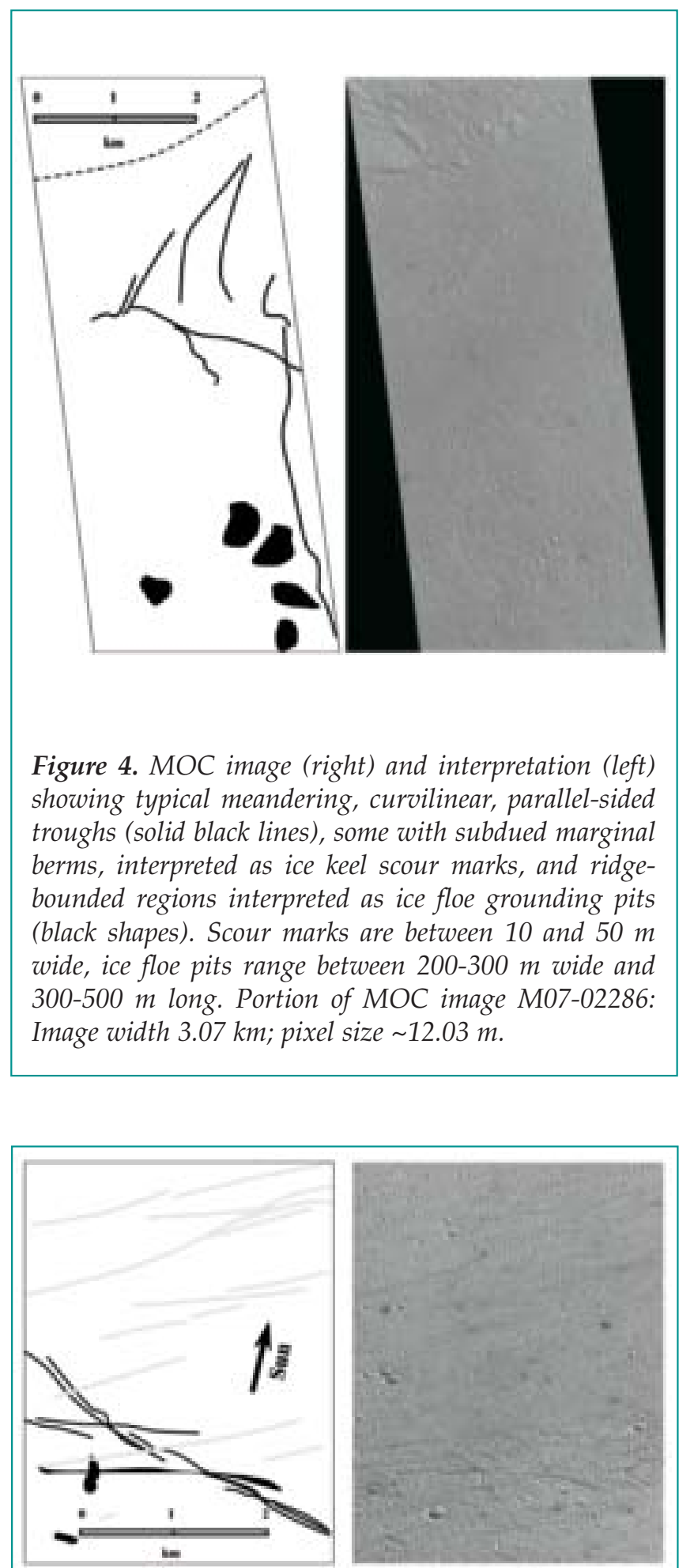

Figure 5. MOC image (right) and interpretation (left) showing typical meandering, curvilinear, parallel-sided troughs (solid black lines), with marginal berms, interpreted as ice keel scour marks and dust devil and wind streaks (grey lines) for comparison. Scour marks 10-20 m wide (wide feature 20-200 m wide); ice floe pits $125 \mathrm{~m}$ wide $\mathcal{E}$ 250-400 m long; wavelength of valley-transverse megaripples (upper portion of image) $=33.3 \mathrm{~m}$. Portion of MOC image E12-02116: Image width $3.24 \mathrm{~km}$; pixel size $\sim 6.33 \mathrm{~m}$

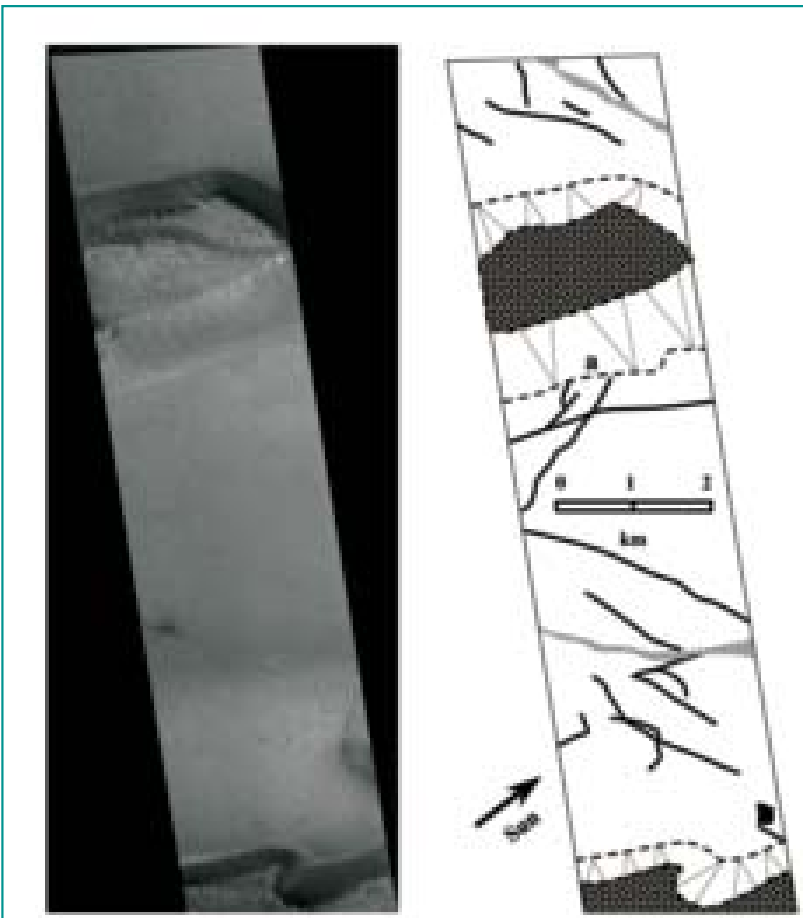

Figure 6. MOC image (left) and interpretation (right) from middle reaches of the southern branch of Kasei Valles showing typical meandering, curvilinear, parallelsided troughs (solid black lines), some with prominent marginal berms, interpreted as ice keel scour marks. The two wider features (diagonal hatching) are interpreted as several coalesced scour marks that represent former Stamukhi zones of horizontal shear in the former floating ice canopy. In the Beaufort Sea Stamukhi zones are typically associated with intense ice keel scouring. All of the ice-related features are superimposed on an extensive field of valley-transverse megaripples. Scour marks at " $a$ " are buried beneath the toe of a talus slope. Scour marks are 10-30 m wide; Stamukhi zones are 50-100 m wide; megaripple wavelength $=33.3 \mathrm{~m}$. The single ice floe grounding pit (black object, bottom right) is $125 x$ $400 \mathrm{~m}$. Portion of MOC image M08-07137: Image width $2.81 \mathrm{~km}$; pixel size $\sim 4.5 \mathrm{~m}$

ridge-defined smooth areas range in size from 200 to 600 $\mathrm{m}$, exceptionally up to $950 \mathrm{~m}$. They may occur as solitary features, but more commonly occur in groups forming jig-saw-like ridge networks (Figure 9). In Echus Chasma these ridge-defined features tend to be of a larger scale (in the range 0.5 to $1.0 \mathrm{~km}$ ) and individual features may contain smaller, well defined jigsaw-like groups of subcircular regions, that are also defined by ridges of a smaller scale than the larger feature in which they are contained (Figure 10). In places, inside the ridge-defined area, a well developed ridge-like linear fabric that is usually discordant with that of its neighbour may additionally distinguish each member of a jigsaw-like group.

In MOC images, where it is observed in Kasei Valles, the rough-textured surface of the valley floor is caused by small-scale, poorly- to moderately 

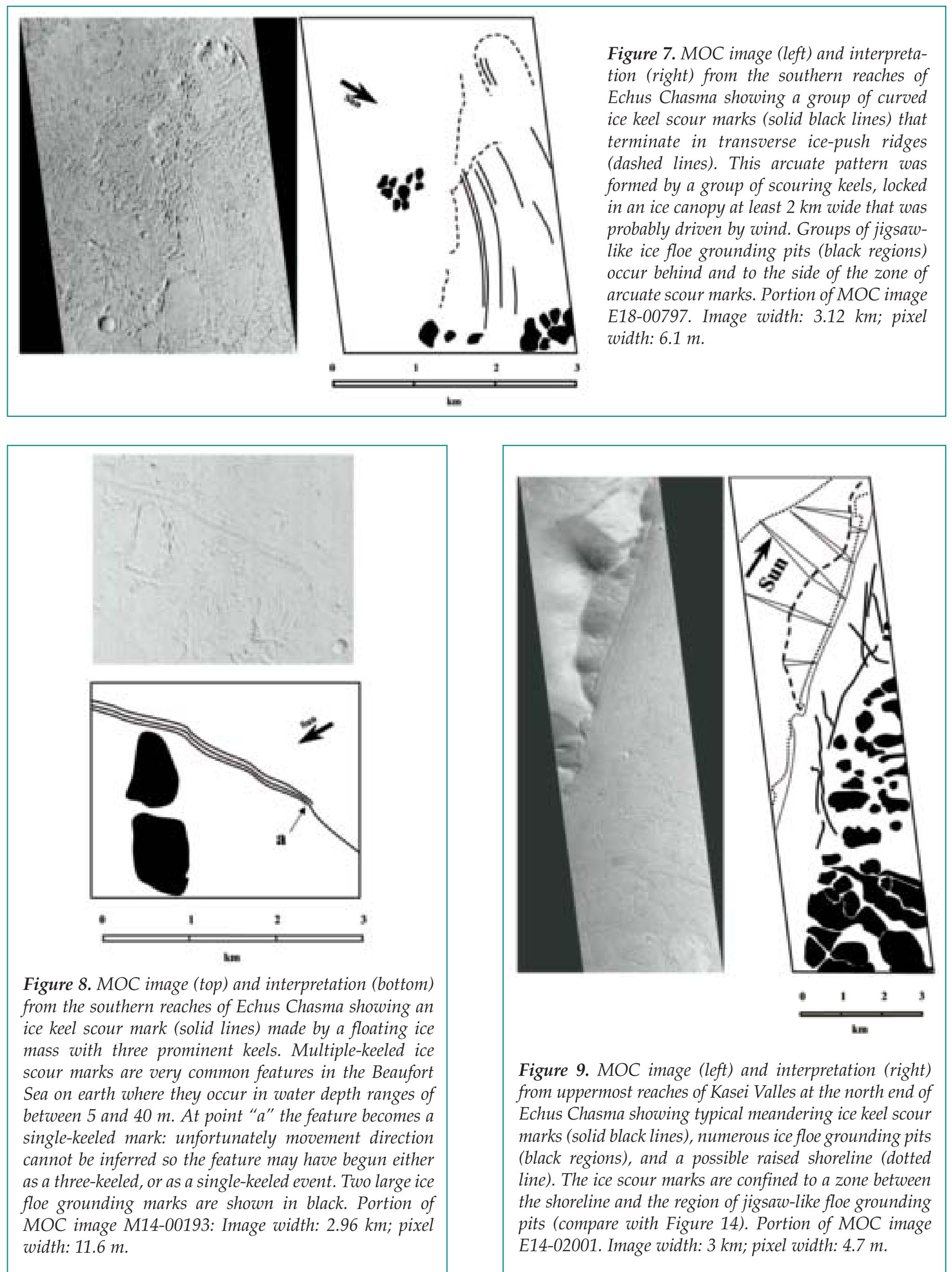

Figure 9. MOC image (left) and interpretation (right) from uppermost reaches of Kasei Valles at the north end of Echus Chasma showing typical meandering ice keel scour marks (solid black lines), numerous ice floe grounding pits (black regions), and a possible raised shoreline (dotted line). The ice scour marks are confined to a zone between the shoreline and the region of jigsaw-like floe grounding pits (compare with Figure 14). Portion of MOC image E14-02001. Image width: $3 \mathrm{~km}$; pixel width: $4.7 \mathrm{~m}$. 


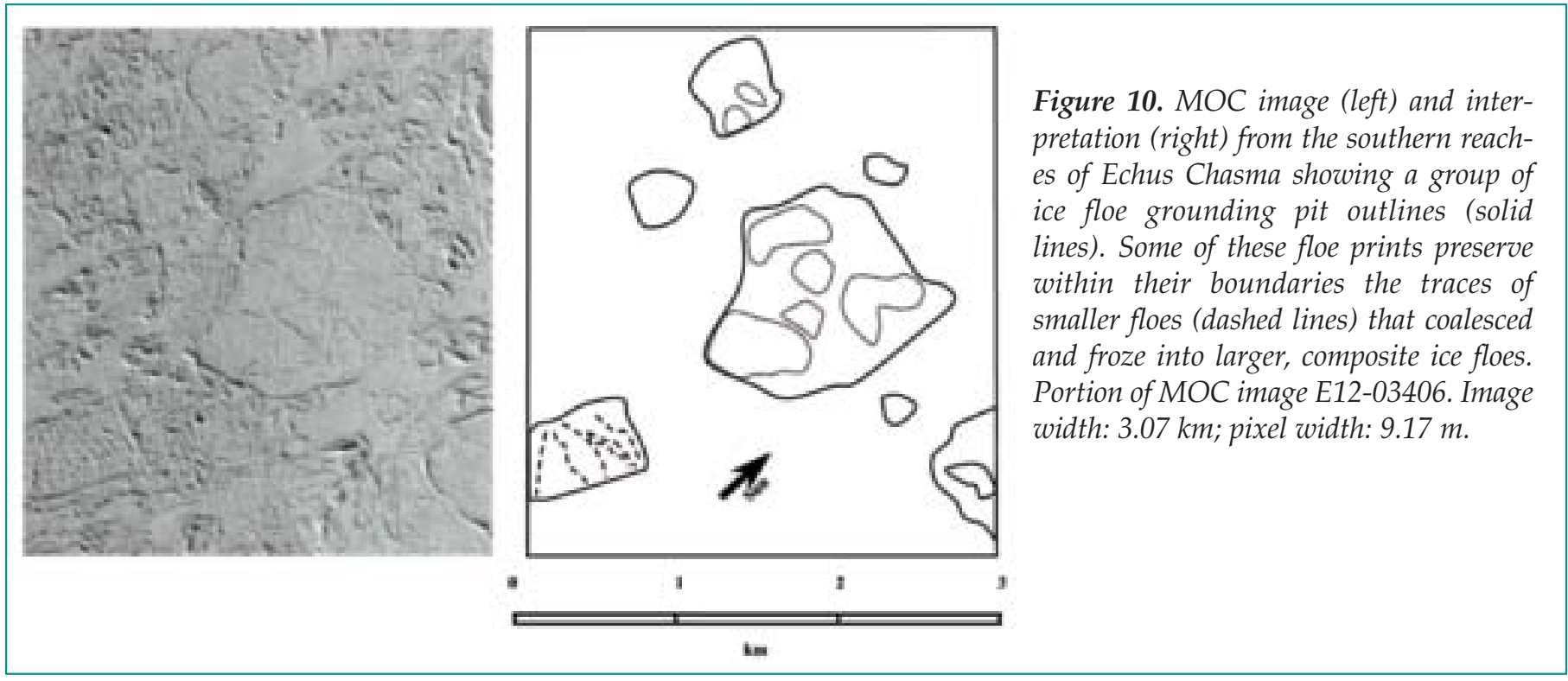

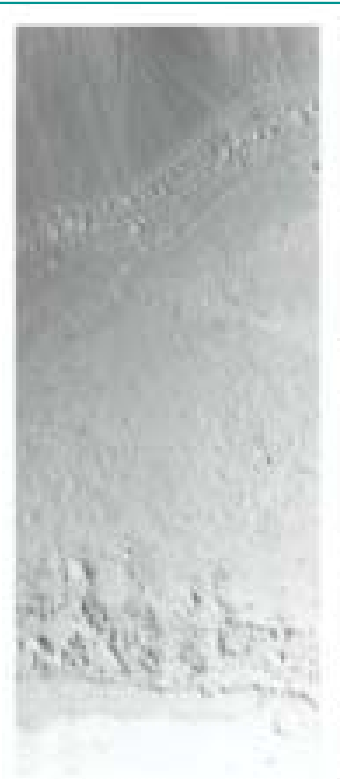

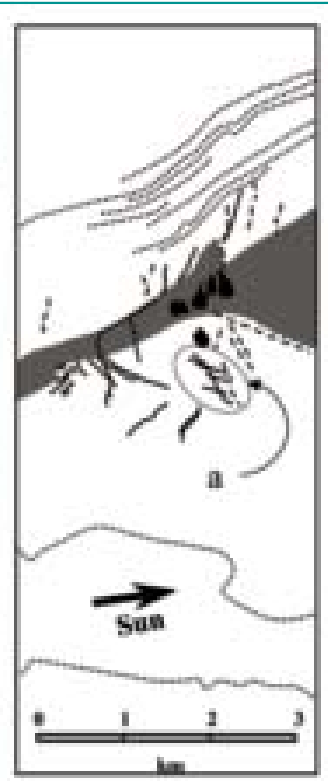

Figure 11. MOC image (left) and interpretation (right) from the western reaches of Kasei Valles near the juncture with Echus Chasma. This image shows scour marks (solid black lines), and ice floe grounding pits (black objects) superimposed on a region of possible ice-push ridges (hatched zone): discrete ice-push ridges (dashed lines) also occur away from this zone. The region labeled " $a$ " is a small group of parallel scour marks that terminate at an ice-push ridge indicating that the scouring keels that formed the push ridge moved from left to right. Raised shorelines (dotted lines), defined by rocky and bouldery slope breaks, are clearly visible on both sides of the valley: as many as nine shorelines can be seen on the north side (top of image). Scour marks $20-30 \mathrm{~m}$ wide, ice floe pits $125-175 \mathrm{~m}$ wide and 250-350 $\mathrm{m}$ long. Portion of MOC image E05-01141: Image width $3.5 \mathrm{~km}$; pixel size $\sim 3.42 \mathrm{~m}$.

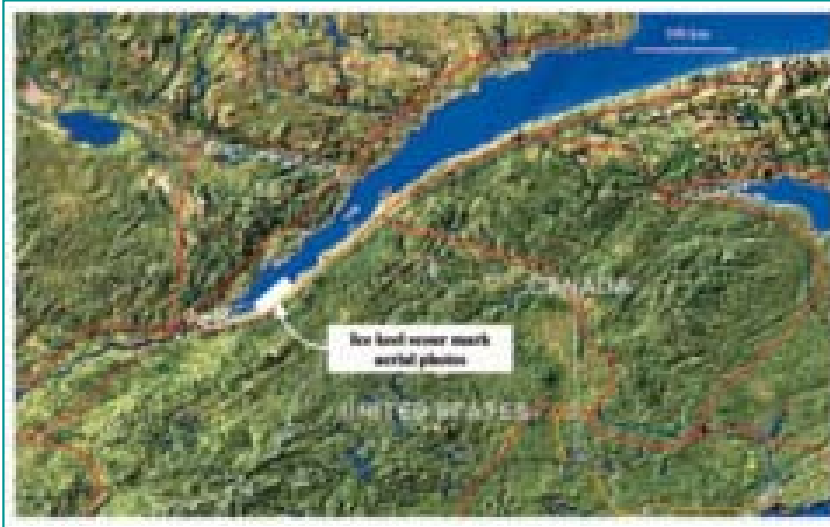

Figure 12. Map showing the location of ice keel scour marks in the St. Lawrence estuary.

well-defined, discontinuous, narrow arcuate lineaments that have the appearance of possible degraded megaripple crests (e.g. Figures 5 and 6). The arcuate lineaments are generally oriented across the valley and are defined by high albedo with a lower albedo, wider inter-lineament area. Wavelengths range between 33 and $40 \mathrm{~m}$.

In places raised shorelines are found in association with the described features. A single possible shoreline was found in association with parallel-sided troughs and ridge-defined regions in Echus Chasma (Figure 9). Multiple older shorelines were found in association with similar features in the upper reaches of Kasei Valles (Figure 11).

\section{Geographical Distribution of Features}

In Kasei Valles the parallel-sided troughs with berms; the multiple, overlapping sub-parallel troughs; the arcuate lineaments and smooth ridge-bounded regions are restricted in their occurrence to the lowest 

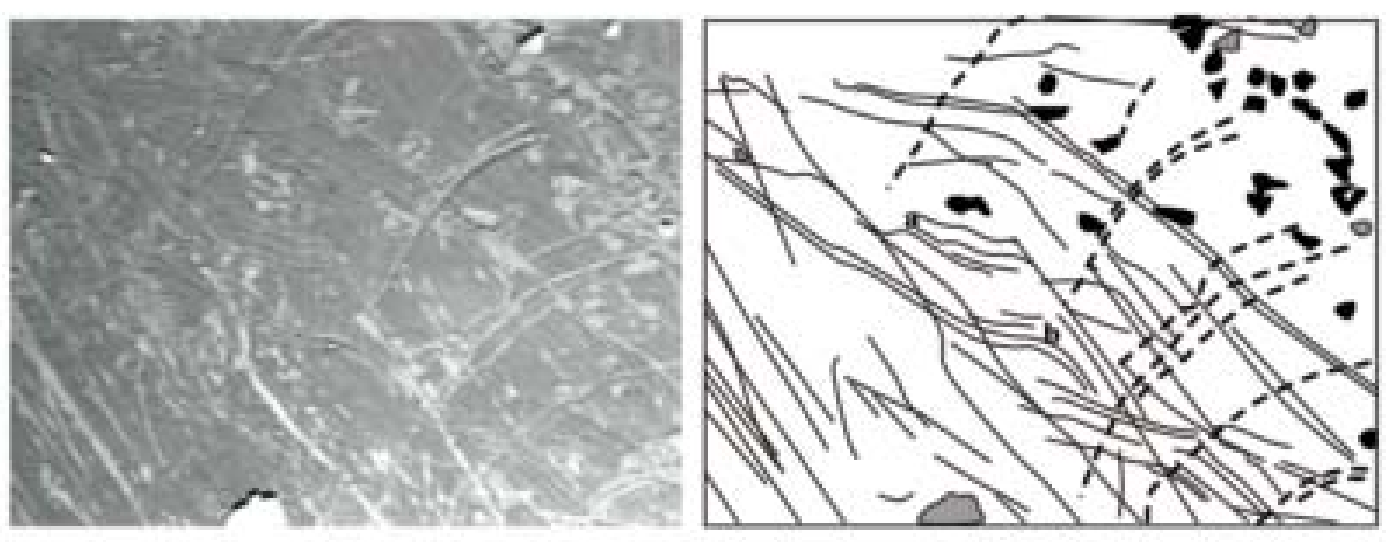

Approx. $750 \mathrm{~m}$

Figure 13. Vertical view (left) and interpretation (right) of ice keel scour marks (solid black lines), ice floe grounding pits (black shapes) and ice floes (dotted shapes): " $a$ " and " $b$ " are multiple-keeled scour marks. Thick dashed lines highlight scour marks that were made during a single event as wind pushed the scouring ice floes at high angles to the general trend of riverparallel scour marks. This group of wind-driven scour marks is comparable with the Echus Chasma scour marks in Figure 7. St. Lawrence estuary (near Montmagny). Aerial photo taken at low tide: image width approx $750 \mathrm{~m}$.
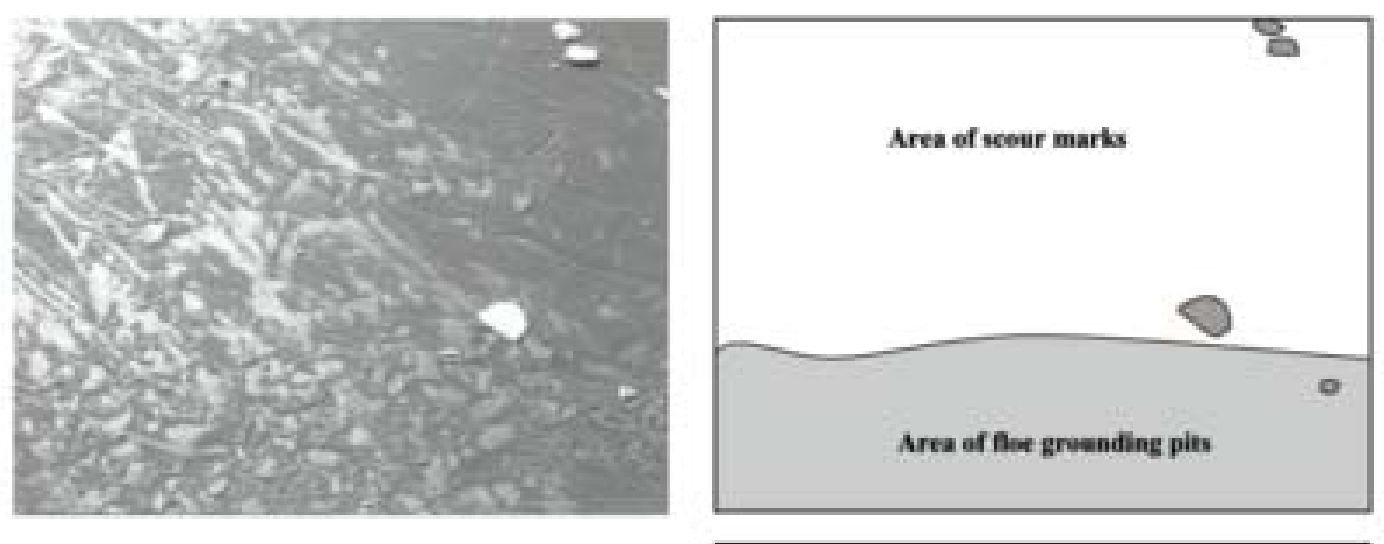

Approx. $750 \mathrm{~m}$

Figure 14. Vertical view (left) and interpretation (right) of ice keel scour marks and a region in the foreground of numerous ice floe grounding pits and ice floes. Compare this zonation of scour marks and grounding pits with Figure 9. St. Lawrence estuary (near Montmagny). Aerial photo taken at low tide: image width approx $750 \mathrm{~m}$.

and flattest portion of the valley floor (Figure 1) and do not occur at or east of the vicinity of Sharanov crater and are not found on any of the elevated, older grooved surfaces of the Kasei system.

Ridge-defined smooth areas are considerably more common, and of larger scale, in the much wider, flat regions of Echus Chasma. Parallel-sided troughs with berms are less common but multiple troughs (Figure 7) and closely-spaced parallel troughs (Figure 8) were found here.

\section{Similar Features on Earth in the \\ St. Lawrence Estuary}

Ice keel scour marks are formed on extensive tidal mud flats during the breakup of river ice each spring in the St. Lawrence estuary (Figure 12). Scour marks are common on mud flats on the southern shore in a stretch at least $125 \mathrm{~km}$ long where the estuary is $15-25$ $\mathrm{km}$ wide. The scour marks are formed in shallow water ( $<1 \mathrm{~m}$ to approximately $3 \mathrm{~m}$ deep) during flood tides 

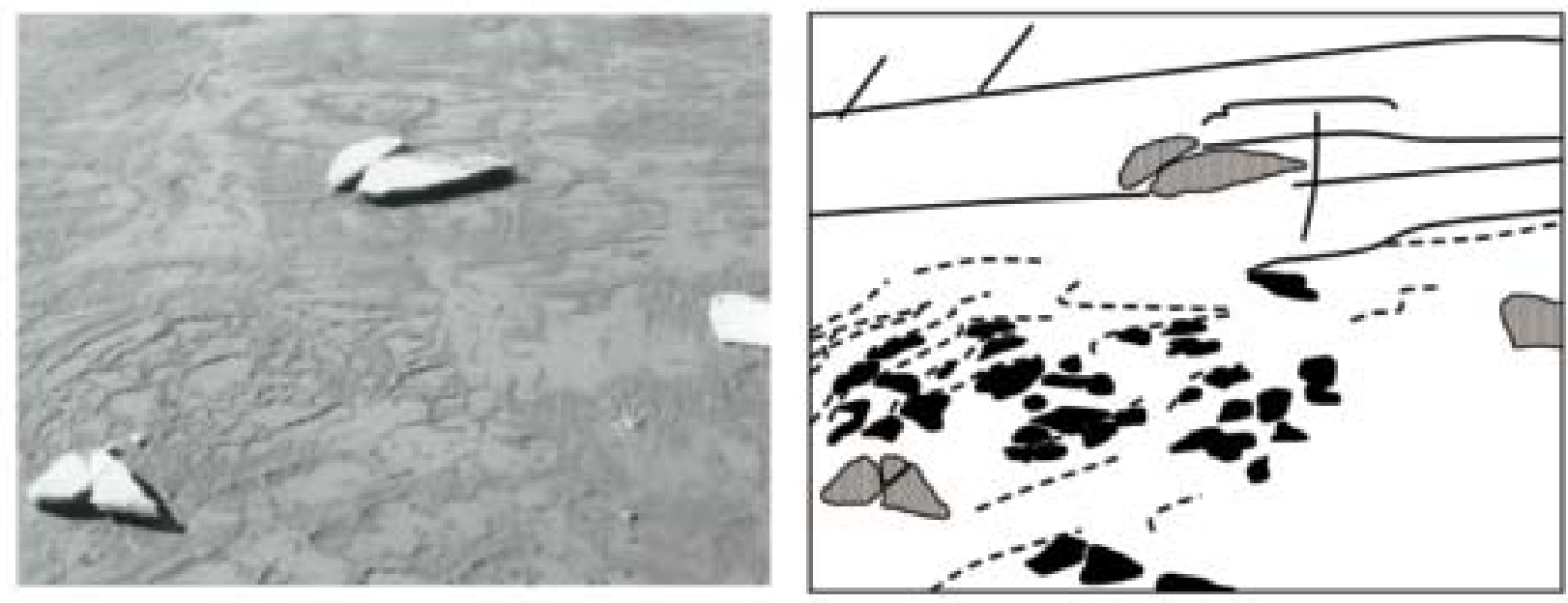

Figure 15. Oblique aerial view (left) and interpretation (right) of ice keel scour marks (solid black lines) and a region in the foreground of numerous ice floe grounding pits (black shapes) and associated ice-push ridges (dashed lines). Ice floes are shown as dotted shapes. Compare this situation with Figure 9. St. Lawrence estuary (near Montmagny). Aerial photo taken at low tide: foreground image width approx $750 \mathrm{~m}$.

and are exposed during low tide (e.g. Dionne, 1972; 1974). The scour marks form a network of curvilinear, parallel-sided troughs that meander and intersect (Figure 13). The troughs range from $1 \mathrm{~m}$ to $30 \mathrm{~m}$ in width. Some troughs are characterized by ridges and grooves formed by irregularities in the base of a single ice keel (Figure 13, features " $a$ " and " $b$ "). The margins of most troughs are characterized by narrow ridges, or berms, formed by the bulldozing and ploughing action of the scouring ice keels. Depending on location there is a preferred orientation of the troughs that roughly parallels the river axis. However networks of scour marks are formed at high angles to the shoreline and are the result of scouring ice masses driven shorewards by strong cross-valley winds (Figure 13).

The scour marks are formed by keels of large, flat first-year ice floes that are typically $20-50 \mathrm{~m}$ in diameter and 1-2 $\mathrm{m}$ thick. Large, composite ice masses that are $3-4 \mathrm{~m}$ thick formed by ice pressure during the winter months have deeper keels and tend to make deeper scour marks in deeper water.

The scour marks are associated with irregularlyshaped depressions, the margins of which are generally characterized by small ridges. These features are grounding pits created by ice floes that become stranded during low tide. As the floes settle into the riverbed, mud is displaced outwards and upwards along the margins to form low ridges that preserve an imprint of the floe. In places large numbers of floes ground together creating jigsaw-like patterns of ridges (Figure 14). Where moving floes ground together the leading edges may create a local system of arcuate ice-push ridges (Figure 15).

\section{Interpretation of Martian features}

We interpret the small-scale troughs on the floor of the Kasei Valles system and in Echus Chasma as ice keel scour marks made by the grounding keels of floating ice floes. We interpret the associated ridge-defined low albedo smooth regions as grounding pits made by stranded tabular floes. Prints formed by grounded composite ice floes are also found in places in Echus Chasma. The megaripple-like surfaces on which the scour marks and grounding pits appear to have formed in the lower Kasei Valles formed during a period of strong unidirectional down-valley currents. There may have been floating ice present and ice scouring may have occurred during megaripple formation but all traces would have been erased or buried by the migrating ripples. As the strong currents associated with the megaripples waned, ice scour marks and ice floe grounding pits formed and were preserved. The meandering tracks of the scour marks point to a significant decrease in unidirectional flow and suggest that winds may have played a significant role in driving the scouring floes.

The group of multiple, sub-parallel, curved troughs in Echus Chasma (Figure 7) is related to a single, ice keel scour event by several, widely separated scouring ice masses. This sub-parallel group of scour marks is directly analogous to the multiple scour marks, shown in Figure 13 that formed during a single event in the St. Lawrence estuary. The Echus Chasma feature in Figure 8 is a scour mark that was made by a single ice mass with multiple keels and is directly analogous to the multi-keeled scour marks (features "a" and " $b$ ") shown in Figure 13 from the St. Lawrence estuary. 
We interpret the wide lanes of multiple, overlapping sub-parallel troughs found in Kasei Valles (Figure 6) as zones marking the boundary between stationary fast ice and moving ice. Shear zones such as these are commonly formed between landfast ice and the offshore arctic pack in the Canadian and U.S. Beaufort Sea. These regions of linear shear in the ice canopy, referred to as Stamukhi zones, are typically linked to intense ice keel scouring of the seafloor (e.g., Barnes et al., 1984; Reimnitz and Barnes, 1974).

\section{Regional Context}

We have found that the ice keels scour marks are restricted in their occurrence to the flat valley floor of Kasei Valles, and to the much wider floor of Echus Chasma. Scour marks are most common in the southern branch of Kasei Valles. We have not yet found traces of ice keel scouring in the valley floors of the Mawrth, Ares, Tiu, Simud and Maja valley systems, and have found no traces in Chryse Planitia near Contact 2.

The geological units that define the six Valles systems emptying into Chryse Planitia span the time interval from mid-Noachian, through the Hesperian and into the early Amazonian (Ivanov and Head, 2001; Tanaka, 1997). The youngest Valles geological unit is the early-Amazonian aged Kasei unit 2 mapped by Rotto and Tanaka (1995) and Tanaka (1997). It is on the surface of this unit that the Kasei Valles ice keel scour marks all formed. The Echus Chasma features occur on the surface of Member 5 of the middle-Amazonian Tharsis Formation (Rotto and Tanaka, 1995; Tanaka, 1997). Unit 2 and Member 5 comprise two of the youngest geological units in this region of Mars.

\section{Discussion and Implications}

Ice keel scour marks on Mars are a proxy indicator of environment, from which the following three fundamental conclusions are drawn, namely that they demonstrate:

1. the former presence of a water body;

2. the water body must have been at least seasonally, or perhaps permanently, covered by ice floes;

3. the water area must have been large enough for wind and current to drive the floes forward during ice/seabed interaction.

Ice keel scour marks and ice floe grounding pits are present on the flat valley floor of the Kasei Valles system and of parts of Echus Chasma and are the most recent surficial features preserved in the Kasei/Echus system. The scour marks are therefore at least of early Amazonian and possibly mid-Amazonian age and are the most recent features preserved in all of the six major valley systems surrounding Chryse Planitia. [ed

\section{Acknowledgements}

The authors gratefully acknowledge the use of Mars Orbiter Camera images processed by Malin
Space Science Systems that are available at http://www.msss.com/moc_gallery/. We are grateful to Peter Wadhams and James Syvitski who reviewed the manuscript.

\section{References}

Barnes, P.W., D.M. Rearic and E. Reimnitz, 1984: Ice gouging characteristics and processes. In: The Alaskan Beaufort Sea-Ecosystems and Environments. Academic Press, Orlando, 185-213.

Dionne, J.C., 1972: Ribbed grooves and tracks in mud tidal flats of cold regions: J. of Sed. Pet., 41, 848-851.

Dionne, J.C., 1974: Polished and striated mud surfaces in the St. Lawrence tidal flats, Québec. Can. J. Earth Sci., 11, 860-866.

Gilbert, R.J., K.J. Handford and J. Shaw, 1992: Ice scours in the sediments of glacial Lake Iroquois, Prince Edward County, eastern Ontario. Geographie Physique et Quaternaire, 46, 189-194.

Ivanov, M.A. and J.W. Head, 2001: Chryse Planitia, Mars: Topographic configuration, outflow channel continuity and sequence, and tests for hypothesized ancient bodies of water using Mars Orbital Laser Altimeter (MOLA) data. J. Geophys. Res., 106 (E2), 3275-3295.

Luchitta, B.K., H.M. Ferguson and C. Summers, 1986: Sedimentary deposits in the northern lowland plains, Mars. J.Geophys. Res., 91 supplement, E166-E174.

Parker, T.J., D.S. Gorsline, R.S. Saunders, D.C. Pieri and D.M. Schneeberger, 1993: Coastal geomorphology of the Martian northern plains. J.Geophys. Res, 98, 11061-11078.

Reimnitz, Erk, and P.W. Barnes, 1974: Sea ice as a geologic agent on the Beaufort Sea shelf of Alaska: In: The Coast and Shelf of the Beaufort Sea. J.C. Reed, and J.E.Sater, eds., Arctic Institute of North America, Arlington, VA, 301-351.

Rotto, S. and K.L. Tanaka, 1995: Geologic/geomorphologic map of the Chryse Planitia region of Mars. U.S. Geological Survey Miscellaneous Investigations Series Map, 1-2441.

Tanaka, K.L., 1997: Sedimentary history and mass flow structures of Chryse and Acidalia Planitiae, Mars. J. of Geophys. Res., 102 (E2), 4131-4149.

Woodworth-Lynas, C.M.T. and J.Y. Guigné, 1990: Iceberg scours in the geological record: examples from glacial Lake Agassiz. In: Glacimarine Environments: processes and sediments. J.A. Dowdeswell and J.D. Scourse, eds., Geol. Soc. Spec. Pub. No., 53, 217-233.

Woodworth-Lynas, C.M.T., 1992: The geology of ice scour. Ph.D. thesis, University of Wales. 